Check for updates

Cite this: RSC Adv., 2017, 7, 48980

Received 7th September 2017

Accepted 11th October 2017

DOI: $10.1039 / c 7 r a 09995 a$

rsc.li/rsc-advances

\title{
Nitrones and nucleobase-containing spiro- isoxazolidines derived from isatin and indanone: solvent-free microwave-assisted stereoselective synthesis and theoretical calculations $\uparrow$
}

\author{
Loredana Maiuolo, (D) *a Pedro Merino, (DD b Vincenzo Algieri, (DD a Monica Nardi, (D) ac \\ Maria Luisa Di Gioia, (iD d Beatrice Russo, (D) a Ignacio Delso, ${ }^{\text {e }}$ \\ Matteo Antonio Tallarida iD a and Antonio De Nino (iD *a
}

\begin{abstract}
The spiro-oxindoles have found wide application because of their antiviral properties. However, in the literature few examples of synthesis of their precursors, oxindole-nitrones, are reported. In this paper, we initially present a rapid and efficient synthetic approach to ketonitrones by solvent-free microwaveassisted reaction between isatin or indanone derivatives and various hydroxylamines. The synthetic protocol is facile, clean, fast, high-yielding and stereoselective. Then, we explored the possibility to synthesize nucleobase-containing spiro-isoxazolidines with isatin and indanone nuclei by solvent-free MW-assisted 1,3-dipolar cycloaddition, obtaining good results in yields (74-85\%), and regio- and diastereoselectivity. Theoretical calculations were done to analyze the difference of reactivity of isatin and indanone derivatives with hydroxylamines.
\end{abstract}

\section{Introduction}

The spiro-oxindole scaffold is the characteristic structural core of numerous alkaloids and unnatural biologically active compounds. ${ }^{1}$ Inspired by this important moiety, a number of methods to synthesize isatin and oxindole derivatives were realized during the last few years. In fact, the biological importance of compounds containing spiro-carbon at the C-3 position of the indoline or oxindole skeleton has recently been emphasized in the literature. ${ }^{2,3}$ In particular, spirooxindoles and spiro-isoxazolidines possess antiviral activity for various human diseases, inhibiting poxvirus, ${ }^{4}$ ectromelia, ${ }^{5}$ rhinovirus, ${ }^{6}$ HIV-1 (ref. 7) and, more recently, as inhibitors of MDM2/p53 interaction..$^{\mathbf{8} 9}$

The 1,3-dipolar cycloaddition between a ketonitrone and a vinylic substrate may be considered a common procedure for

${ }^{a}$ Dipartimento di Chimica e Tecnologie Chimiche, Università della Calabria, Via P. Bucci, cubo 12C,87036 Rende, CS, Italy. E-mail: maiuolo@unical.it; denino@ unical.it

${ }^{b}$ Institute of Biocomputation and Physics of Complex Systems (BIFI), Universidad de Zaragoza-CSIC, 50009 Zaragoza, Spain

'Dipartimento di Agraria, Università Telematica San Raffaele, Via di Val Cannuta, 247, Roma, 00166, Italy

${ }^{d}$ Dipartimento di Farmacia e Scienze della Salute e della Nutrizione, Università della Calabria, Edificio Polifunzionale, 87036 Rende, CS, Italy

${ }^{e}$ Servicio de Resonancia Magnética Nuclear, CEQMA, Universidad de Zaragoza-CSIC, 50009 Zaragoza, Spain

$\dagger$ Electronic supplementary information (ESI) available. See DOI: 10.1039/c7ra09995a the preparation of these compounds. ${ }^{10-12}$ Although a broad range of methodologies to synthesis of aldonitrones is available today, ${ }^{\mathbf{1 3 - 2 0}}$ in contrast the preparation of ketonitrones is not always accomplished by simple condensation reaction. ${ }^{21-23} \mathrm{~A}$ thorough search of the relevant literature yielded only few articles related to synthetic procedures of isatin and oxindole nitrone. ${ }^{24,25}$ In particular, a methodology regards the preparation of $\mathrm{N}$-substituted isatin nitrones via a multi-step reaction sequence. ${ }^{26}$

Recently, the synthesis of ( $Z$ )- $N$-aryl oxindole nitrones was performed through a $\mathrm{N}$-arylation of 3-(hydroxyimino) indolin-2ones with diaryliodonium salts, demonstrating the current interest in having efficient routes towards those sort of nitrones. ${ }^{27}$ On the contrary, to our knowledge, methodologies of indanone nitrones are not present in literature.

As a result, the development of a simple and convenient method for the synthesis of isatinyl and indanyl nitrones realized from ketones and hydroxylamines through mild conditions could be highly desirable.

In recent years, the use of microwave technology in organic chemistry, allows to prepare organic compounds very fastly, with high purity and better yield respect to other conventional methods. $^{28,29}$

Recently, we described a green approach to synthesize aldoand ketonitrones by solvent-free condensation of alkyl- or arylhydroxylamines hydrochlorides with aromatic aldehydes and ketones under microwave irradiation, bypassing the critical results obtained with ketonitrones. ${ }^{30}$ 
Then, in present work, we firstly describe a facile synthesis of isatinyl and indanyl nitrones via microwave-assisted reaction between ketones and hydroxylamines under solvent-free conditions. In our approach, we observed very short reaction times and a reduced formation of by-products, isolating the expected products in high yields and excellent stereoselectivity. Successively, we report for the first time a regio- and diastereomeric synthesis of nucleobase-containing spiroisoxazolidines with an indoline or an indane ring by $\mathrm{MW}$ assisted 1,3-dipolar cycloaddition, obtained in yields between $74-85 \%$ and via solvent-free procedure.

\section{Results and discussion}

To find the optimal conditions for the synthesis of nitrones, we chose $N$-methylhydroxylamine hydrochloride $\mathbf{1 a}$ and 1-isatin $\mathbf{2 a}$ and indanone 3a as ketones. The methodology consists of the co-grinding of the ketone and hydroxylamine in a mortar, followed by transfer of the mixture in a sealed vessel and further mixing by a vortex; finally the mixture is placed in a microwave oven. The optimization study is collected in Table 1 .

The best conditions for both ketones (entries 5 and 11) were those corresponding to an irradiation of $600 \mathrm{~W}\left(T=180^{\circ} \mathrm{C}\right)$ for $10 \mathrm{~min}$ for ketone $2 \mathrm{a}$ and an irradiation of $400 \mathrm{~W}\left(T=180^{\circ} \mathrm{C}\right)$ for $30 \mathrm{~min}$ for ketone $\mathbf{3 a}$. The corresponding products $\mathbf{4 a}$ and $\mathbf{5 a}$ were obtained in $97 \%$ and $82 \%$ chemical yield, respectively. In both cases, nitrones were obtained as single isomers, $E$-4a and $Z$-5a respectively, as confirmed by NOESY experiments. When the reaction was carried out in $\mathrm{EtOH} / \mathrm{H}_{2} \mathrm{O}$ as a solvent and in the

Table 1 Optimization of isatinyl and indanyl nitrones synthesis ${ }^{a}$

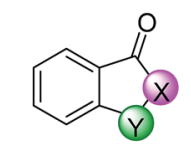

2a $\mathrm{X}=\mathrm{C}=\mathrm{O} ; \mathrm{Y}=\mathrm{NH}$ 3a $X=Y=\mathrm{CH}_{2}$
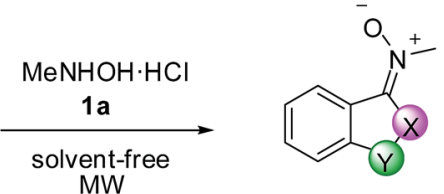

4a $\mathrm{X}=\mathrm{C}=\mathrm{O} ; \mathrm{Y}=\mathrm{NH}$ 5a $\mathrm{X}=\mathrm{Y}=\mathrm{CH}_{2}$

\begin{tabular}{lllllll}
\hline Entry & Ketone $^{b}$ & MW $(\mathrm{W})$ & $T\left({ }^{\circ} \mathrm{C}\right)$ & Time $(\mathrm{min})$ & Product & Yield (\%) \\
\hline $1^{c}$ & $\mathbf{2 a}$ & 200 & 180 & 10 & $\mathbf{4 a}$ & 33 \\
$2^{c}$ & $\mathbf{2 a}$ & 400 & 180 & 10 & $\mathbf{4 a}$ & 42 \\
3 & $\mathbf{2 a}$ & 400 & 180 & 10 & $\mathbf{4 a}$ & 53 \\
4 & $\mathbf{2 a}$ & 400 & 180 & 20 & $\mathbf{4 a}$ & 61 \\
5 & $\mathbf{2 a}$ & 600 & 180 & 10 & $\mathbf{4 a}$ & 97 \\
$6^{d}$ & $\mathbf{2 a}$ & 600 & 180 & 10 & $\mathbf{4 a}$ & 80 \\
$7^{e}$ & $\mathbf{2 a}$ & - & $\mathrm{rt}$ & 1440 & $\mathbf{4 a}$ & 70 \\
8 & $\mathbf{3 a}$ & 600 & 180 & 10 & $\mathbf{5 a}$ & 37 \\
9 & $\mathbf{3 a}$ & 600 & 180 & 15 & $\mathbf{5 a}$ & 51 \\
10 & $\mathbf{3 a}$ & 400 & 180 & 10 & $\mathbf{5 a}$ & 25 \\
11 & $\mathbf{3 a}$ & 400 & 180 & 30 & $\mathbf{5 a}$ & 82 \\
$12^{d}$ & $\mathbf{3 a}$ & - & $\mathrm{rt}$ & 1440 & $\mathbf{5 a}$ & 78
\end{tabular}

${ }^{a}$ Reaction conditions: 2.0 eq. of 1a were used unless otherwise indicated. $^{b} 1.0$ eq. was used. ${ }^{c} 1.0$ eq. of 1 a was used. ${ }^{d} 1.0$ eq. of NaOAc was added. ${ }^{e} 1: 1 \mathrm{EtOH} /$ water was used as a solvent and 2.0 eq. of NaOAc were added. presence of 2 equivalent of sodium acetate as reported in literature on similar substrates, ${ }^{\mathbf{3 1}}$ compounds $\mathbf{4 a}$ and $5 \mathbf{a}$ were obtained in $70 \%$ and $78 \%$ chemical yield, respectively, in 24 hours (entries 7 and 12). Moreover, the presence of sodium acetate in reaction mixture does not significantly change the trend of the reaction (entry 6) and therefore we chose not to use it.

In an effort to expand the scope of the reaction, we explored coupling of substituted ketones with $N$-methyl hydroxylamine hydrochloride (1a) $N$-benzyl hydroxylamine hydrochloride (1b),$^{32} N$-phenyl hydroxylamine (1c) ${ }^{33} \quad \mathrm{~N}$-3-chloro-phenyl hydroxylamine (1d) and $N$-t-butylhydroxylamine hydrochloride (1e) (Table 2).

The reaction works well with various isatin ketones 2 and we noticed that the presence of an electron-withdrawing group $(\mathrm{Br}$ or $\mathrm{NO}_{2}$ ) on $\mathrm{C}-5$ of phenyl ring of isatin does not significantly alters their performance (entries 8-13). Methylation of nitrogen does not reduce the reactivity (entries 4-7). Phenylhydroxylamine 1c was used in further excess (ratio ketone/ phenylhydroxylamine $1: 3$ ) because of its known degradability at temperature higher than $50{ }^{\circ} \mathrm{C} .{ }^{34}$ Attempts to reduce byproducts by lowering power of MW (200 or $400 \mathrm{~W}$ ) or by reducing the maxim temperature were unnecessary. In all cases the $E$-isomer was the only obtained with the exceptions of compounds $\mathbf{4 d}$ and $\mathbf{4 h}$ for which small quantities of $Z$ isomers (ratio $E / Z: 78: 22$ and $75: 25$ for $\mathbf{4 d}$ and $\mathbf{4 h}$, respectively) were obtained. In general, ketones 3 present lower reactivity with respect to isatin ketones 2 . In all cases, the $Z$-isomer was the only obtained. When an alkyl group is present on the 2-C or 3-C of the carbon backbone of indanone ring (entries 17 and 18), the yield drops presumably due to a minor electrophilicity of carbonyl group. The propyl group introduces additional steric hindrance, and the yield drops to $20 \%$ (entry 19 ).

The presence of $\mathrm{Br}$ or $\mathrm{F}$ in $\mathrm{C}-5$ of indanone ring (entries 20 and 21) does not produce significant differences of reactivity respect to unsubstituted indanone. On the other hand, the reaction is very sensitive to the size of the cycloalkyl ring (tetralone versus indanone). Tetralone derivatives showed very little reactivity and longer reaction times than other substrates (entries 25-27) are required for obtaining just traces of products.

Moreover, resonance effect in C-4 or in C-7 of isatine and indanone ring (entries 14, 22 and 23) causes major reaction times and/or minor yields because the electrophilicity of the acceptor carbonyl group is reduced. Unfortunately, the large size of $t$-butyl group of 1e dramatically influences both reactions of isatin $\mathbf{2 a}$ and indanone $\mathbf{3 a}$, not leading to the formation of any product (entries 15 and 24). Attempts to carry out the reactions using the conditions previously applied in entries 7 and 12 of Table 1 confirmed the reaction trend, revealing that these reactions are sensitive to steric effects.

As a follow-up work, some nucleobase-containing spiroisoxazolidines with an indoline or an indane ring were synthesized by MW-assisted 1,3-dipolar cycloaddition between nitrones as dipole and vinylnucleobases as dipolarophile. It is generally been recognized that the incorporating of different bioactive scaffolds into one molecule is the powerful strategy to 


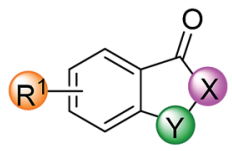

2a-e; 3a-j

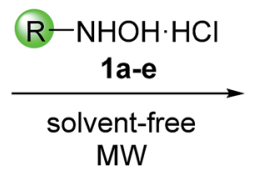

MW

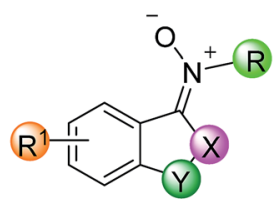

4b-p; 5b-n

\begin{tabular}{|c|c|c|c|c|c|c|c|c|c|}
\hline Entry & Hydroxylamine & $\mathrm{R}$ & Ketone & $\mathrm{X}$ & $\mathrm{Y}$ & $\mathrm{R}^{1}$ & Time (min) & Product & Yield (\%) \\
\hline 1 & $1 \mathbf{b}$ & $\mathrm{Bn}$ & $2 a$ & $\mathrm{C}=\mathrm{O}$ & $\mathrm{NH}$ & $\mathrm{H}$ & 12 & $4 b$ & 95 \\
\hline 2 & $1 \mathrm{c}$ & $\mathrm{Ph}^{a}$ & $2 a$ & $\mathrm{C}=\mathrm{O}$ & $\mathrm{NH}$ & $\mathrm{H}$ & 10 & $4 c$ & 92 \\
\hline 4 & $1 \mathrm{a}$ & $\mathrm{Me}$ & $2 \mathbf{b}$ & $\mathrm{C}=\mathrm{O}$ & $\mathrm{NMe}$ & $\mathrm{H}$ & 10 & $4 e$ & 90 \\
\hline 5 & $1 b$ & $\mathrm{Bn}$ & $2 b$ & $\mathrm{C}=\mathrm{O}$ & $\mathrm{NMe}$ & $\mathrm{H}$ & 12 & $4 f$ & 92 \\
\hline 6 & $1 \mathrm{c}$ & $\mathrm{Ph}^{a}$ & $2 b$ & $\mathrm{C}=\mathrm{O}$ & $\mathrm{NMe}$ & $\mathrm{H}$ & 10 & $4 \mathrm{~g}$ & 90 \\
\hline 9 & $1 b$ & $\mathrm{Bn}$ & $2 c$ & $\mathrm{C}=\mathrm{O}$ & $\mathrm{NH}$ & $5-\mathrm{Br}$ & 10 & $4 \mathrm{j}$ & 93 \\
\hline 10 & $1 \mathrm{c}$ & $\mathrm{Ph}^{a}$ & $2 c$ & $\mathrm{C}=\mathrm{O}$ & $\mathrm{NH}$ & $5-\mathrm{Br}$ & 10 & $4 k$ & 92 \\
\hline 11 & $1 \mathrm{a}$ & $\mathrm{Me}$ & $2 d$ & $\mathrm{C}=\mathrm{O}$ & NH & $5-\mathrm{NO}_{2}$ & 10 & 41 & 95 \\
\hline 12 & $1 b$ & $\mathrm{Bn}$ & $2 d$ & $\mathrm{C}=\mathrm{O}$ & $\mathrm{NH}$ & $5-\mathrm{NO}_{2}$ & 13 & $4 \mathrm{~m}$ & 92 \\
\hline 13 & $1 \mathrm{c}$ & $\mathrm{Ph}^{a}$ & $2 d$ & $\mathrm{C}=\mathrm{O}$ & NH & $5-\mathrm{NO}_{2}$ & 10 & $4 n$ & 92 \\
\hline 14 & $1 \mathrm{a}$ & $\mathrm{Me}$ & $2 e$ & $\mathrm{C}=\mathrm{O}$ & $\mathrm{NH}$ & $5,7-\mathrm{Cl}$ & 25 & 40 & 80 \\
\hline 19 & $1 \mathrm{a}$ & $\mathrm{Me}$ & $3 d$ & $\mathrm{CH}^{n} \mathrm{Pr}$ & $\mathrm{CH}_{2}$ & $\mathrm{H}$ & 32 & $5 e$ & 20 \\
\hline 20 & $1 a$ & $\mathrm{Me}$ & $3 e$ & $\mathrm{CH}_{2}$ & $\mathrm{CH}_{2}$ & $5-\mathrm{Br}$ & 30 & $5 f$ & 88 \\
\hline 21 & $1 \mathrm{a}$ & $\mathrm{Me}$ & $3 f$ & $\mathrm{CH}_{2}$ & $\mathrm{CH}_{2}$ & $5-\mathrm{F}$ & 28 & $5 g$ & 83 \\
\hline 22 & $1 a$ & $\mathrm{Me}$ & $3 g$ & $\mathrm{CH}_{2}$ & $\mathrm{CH}_{2}$ & 4-Br-7-OH & 60 & $5 h$ & 67 \\
\hline 23 & $1 b$ & $\mathrm{Bn}$ & $3 g$ & $\mathrm{CH}_{2}$ & $\mathrm{CH}_{2}$ & 4-Br-7-OH & 48 & $5 i$ & 78 \\
\hline 24 & $1 \mathrm{e}$ & $t-\mathrm{Bu}$ & $3 a$ & $\mathrm{CH}_{2}$ & $\mathrm{CH}_{2}$ & $\mathrm{H}$ & 60 & $5 \mathbf{j}$ & - \\
\hline 25 & $1 \mathrm{a}$ & $\mathrm{Me}$ & $3 h$ & $\mathrm{CH}_{2}$ & $\mathrm{CH}_{2} \mathrm{CH}_{2}$ & $\mathrm{H}$ & 50 & $5 k$ & Traces \\
\hline 26 & $1 b$ & $\mathrm{Bn}$ & $3 h$ & $\mathrm{CH}_{2}$ & $\mathrm{CH}_{2} \mathrm{CH}_{2}$ & $\mathrm{H}$ & 50 & 51 & Traces \\
\hline 27 & $1 \mathrm{a}$ & $\mathrm{Me}$ & $3 \mathbf{i}$ & $\mathrm{CH}_{2}$ & $\mathrm{CH}_{2} \mathrm{CH}_{2}$ & $7-\mathrm{F}$ & 45 & $5 \mathrm{~m}$ & Traces \\
\hline 28 & $1 a$ & $\mathrm{Me}$ & $3 \mathbf{j}$ & $\mathrm{CH}_{2}$ & $\mathrm{CH}_{2} \mathrm{CH}_{2}$ & 6-OMe & 55 & $5 n$ & - \\
\hline
\end{tabular}

${ }^{a}$ Ketone/phenylhydroxylamine ratio $1: 3$.

construct substrates with structural novelty and biological potential.

Considering that, some spiroindoline-isoxazolidines have shown different degrees of anticancer activity mainly based on the isoxazolidine ring fused at C-3 position of oxindole backbone ${ }^{35-37}$ we hypothesized that the simultaneous presence of an spiro carbon, an oxindole-like ring, an isoxazolidine portion and a nucleobase might generate novel molecular entities with amplified anticancer activity as, for example, inhibitors of MDM2/p53 interaction. Moreover, to our knowledge, in literature spiro-isoxazolidines with nucleobases and indoline or indane ring on their backbone have been never synthesized.

As is well known, the typical insertion of a nucleobase on a sugar or isoxazolidine scaffold consists of the method of Vorbrüggen, ${ }^{38}$ but for a long time now, we have developed a simple method by solvent-free MW-assisted 1,3-dipolar cycloaddition between nitrones as dipole and vinylnucleobases $^{39}$ as dipolarophile. ${ }^{40}$
The formation reactions between $N$-1-vinylthymine $6 \mathbf{a}$ and nitrones $\mathbf{4 e}$ and $\mathbf{5 a}$, respectively, were taken as examples for optimization of reaction conditions. The target conjugates were prepared following the synthetic procedure similar to ketonitrones previously prepared, consisting of the co-grinding of the ketonitrone and vinylnucleobase in a mortar, followed by transfer of the mixture in an appropriate vessel and further mixing of the solids in a vortex without use of solvents; finally the solid mixture was placed in a microwave oven. The results are summarized in Table 3.

We prevalently changed the MW power that, based upon our experience, turns out to be the key parameter in MW-assisted cycloadditions, by keeping the nitrone/vinylnucleobase ratio to $2: 1$, respectively. The optimized conditions for the formation of $7 \mathbf{a}$ are listed in entry 3 (Table 3 ). On the contrary, the indanone nucleus obliged us to reduce maintained temperature $\left(T=125{ }^{\circ} \mathrm{C}\right)$ to avoid the formation of a lot quantity of byproducts (entries 5-10, Table 3). Despite everything, reaction 


\begin{tabular}{|c|c|c|c|c|c|c|c|}
\hline Entry & Nitrone $^{b}$ & MW (W) & $T\left({ }^{\circ} \mathrm{C}\right)$ & Solvent & Time (min) & Product & Yield (\%) \\
\hline 1 & $4 e$ & 650 & 180 & - & 30 & $7 a$ & 59 \\
\hline 2 & $4 e$ & 750 & 180 & - & 20 & $7 \mathbf{a}$ & 62 \\
\hline 7 & $5 a$ & 650 & 125 & - & 30 & $8 a$ & 38 \\
\hline 8 & $5 a$ & 750 & 80 & - & 10 & $8 a$ & 41 \\
\hline 9 & $5 a$ & 750 & 100 & - & 30 & $8 a$ & 61 \\
\hline 10 & $5 a$ & 750 & 125 & - & 30 & $8 a$ & 77 \\
\hline 11 & $5 a$ & - & 110 & Toluene & 4320 & $8 a$ & 20 \\
\hline
\end{tabular}

times were major respect to isatin derivatives and yields were good (entry 10, Table 3). Finally, we compared our results with those obtained from classical conditions of 1,3-dipolar cycloaddition, using toluene and reflux (entries 4 and 11, Table 3). It is possible to highlight that reaction times had to be extended to three days, obtaining very poor yields and many by-products.

Then, the reaction conditions of $7 \mathbf{a}$ and $8 \mathbf{a}$ were expanded to the formation of some substituted nucleobase-containing spiroisoxazolidines, using various our nitrones and some vinylnucleobases ( $N$-1-vinylthymine 6 a or $N$-1-vinyluracil $6 \mathbf{b}$ ). The results are collected in Table 4 . All cycloadducts were isolated in good yields and short reaction times (8-30 minutes). The effect of substituents on indoline ring was also investigated, observing slightly yields in presence of bromo or nitro group as substituents because of formation of by-products (entries 5-7, Table 4). All cycloaddition reactions were highly regioselective and goodly diasteroselective, furnishing only one regioisomer (5-substituted) and prevalent exo-adduct (Table 4), as confirmed through NOESY experiments. In particular, we observed a specific correlation between the proton on C-6 of thymine or uracil and the proton on $\mathrm{C}-4$ of aromatic ring, only possible in the exo approach of cycloaddition.

\section{Theoretical calculations}

In order to correlate the reactivity of ketones with hydroxylamines we evaluated the electrophilicity of both reagents by calculating $\omega$ reactivity index. The $\omega$ index establishes an absolute scale of electrophilicity in the sense that the hierarchy of electrophilicity is built up from the electronic structure of molecules. The electrophilicity hierarchy may be systematically rationalized on the basis of substituent effects. As a result, electron-withdrawing groups lead to electrophilic activation, and electron-releasing groups lead to electrophilic deactivation. Accordingly, by establishing a scale in which electrophiles and nucleophiles are present, couples of reagents (ketones and hydroxylamines in our case) presenting large differences of electrophilicity (i.e. $\Delta \omega>2.0$ ) will be the more reactive.

Calculations were carried out at b3lyp-d3bj/def2svp level of theory according to the procedure described elsewhere. We considered the experimentally studied ketones $\mathbf{2 a - e}$ and $\mathbf{3 a}-\mathbf{j}$ but also ketones $\mathbf{2 f - k}$, 3k-3p were calculated in order to predict an extended reactivity. The results are illustrated in Fig. 1.

Among the ketones the most electrophilic one is predicted to be 2d, which has been studied experimentally. Among the hydroxylamines the most nucleophilic one resulted 1a, also experimentally studied. Consequently, the reaction between $\mathbf{2 d}$ and 1a (Table 2, entry 11) is the most favoured as, indeed, is experimentally demonstrated (high yield and only $10 \mathrm{~min}$ of reaction). In general, isatin derivatives are the most reactive with values of $\Delta \omega>2$ with some exception. The lower reactivity predicted $(\Delta \omega<2)$ for indanyl and tetralonyl derivatives is experimentally confirmed by the longer reaction times required and lower yields obtained. In fact, the absence of product obtained for the reaction between ketone $\mathbf{3} \mathbf{j}$ and hydroxylamine $\mathbf{1 a}$ correlates with a low difference in electrophilicity $(\Delta \omega=1.11)$.

\section{Experimental}

Commercial starting materials were used without further purification. Reactions were monitored by TLC using silica plates 60-F264, commercially available from Merk. ${ }^{1} \mathrm{H}$ and ${ }^{13} \mathrm{C}$ NMR 
Table 4 MW-assisted synthesis of nucleobase-containing spiro-isoxazolidines

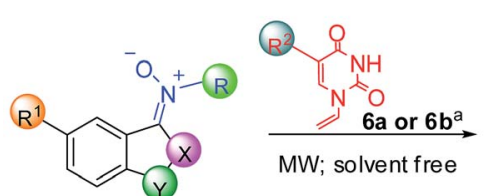

$4 \mathrm{~b}-\mathrm{c} ; 4 \mathrm{e} ; 4 \mathrm{i} ; 4 \mathrm{j} ; 4 \mathrm{l} ; 5 \mathrm{a}$ 6a: $R^{2}=M e$ 6b: $R^{2}=H$<smiles>O=C(O)C1(c2cccc(Br)c2)CC(n2cc(O)c(=O)[nH]c2=O)N(O)O1</smiles>

$7 b-h ; 8 b$

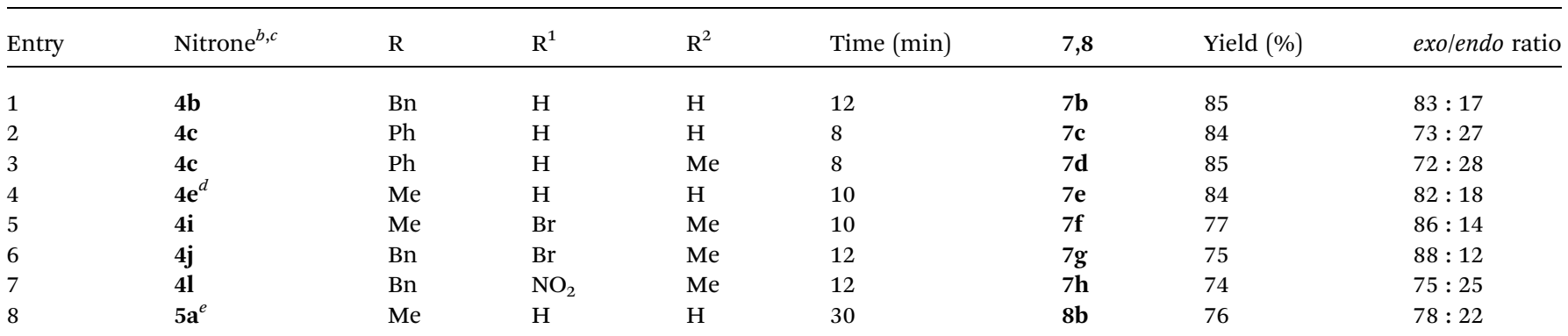

${ }^{a} 1.0$ eq. of $6 \mathbf{a}$ or $\mathbf{6 b}$ were used. ${ }^{b} 2.0$ eq. was used. ${ }^{c} \mathrm{X}=\mathrm{CO} ; \mathrm{Y}=\mathrm{NH}$ unless otherwise indicated. ${ }^{d} \mathrm{Y}=\mathrm{NMe}^{e} \mathrm{X}=\mathrm{Y}=\mathrm{CH}_{2}$.

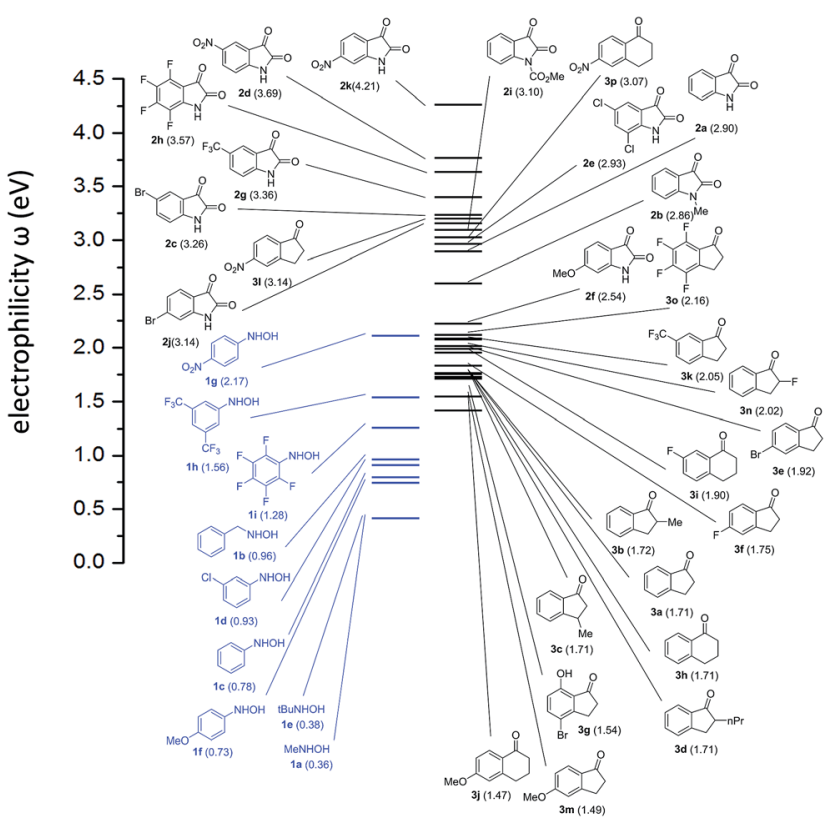

Fig. 1 Electrophilicity ( $\omega$ in eV) scale for ketones and hydroxylamines.

spectra were recorded at 300, 400 and $500 \mathrm{MHz}$ and 75, 100 and $125 \mathrm{MHz}$, respectively, in $\mathrm{CDCl}_{3}$ and $\mathrm{DMSO}-\mathrm{d}_{6}$ using tetramethylsilane (TMS) as internal standard (Bruker ACP $300 \mathrm{MHz}, 400$ $\mathrm{MHz}$ and $500 \mathrm{MHz}$ ). Chemical shifts are given in parts per million and coupling constants in Hertz. The stereochemistry were established by NOESY experiments.

LC-MS analysis were carried using an Agilent 6540 UHD Accurate - Mass Q-TOF LC-MS (Agilent, Santa Clara, CA) fitted with a electrospray ionisation source (Dual AJS ESI) operating in positive ion mode. Chromatographic separation was achieved using a C18 RP analytical column (Poroshell 120, SB-C18, $50 \times$ $2.1 \mathrm{~mm}, 2.7 \mu \mathrm{m})$ at $30{ }^{\circ} \mathrm{C}$ with a elution gradient from $5 \%$ to $95 \%$ of $\mathrm{B}$ over 13 min., a being $\mathrm{H}_{2} \mathrm{O}(0.1 \% \mathrm{FA})$ and $\mathrm{B}^{\mathrm{CH}_{3} \mathrm{CN}}$ (0.1\% FA). Flow rate was $0.4 \mathrm{~mL} \mathrm{~min}^{-1}$.

MW-assisted reactions were performed in Synthos 3000 instrument from Anton Paar, equipped with a $4 \times 24 \mathrm{MG} 5$ rotor and an IR probe as external control of the temperature. 0.3$3 \mathrm{~mL}$ glass vials sealed with a dedicated PEEK screw-cup together with a reliable PTFE seal were used for all reactions. In synthesis of all derivatives the setting of temperature was always maintained to $180{ }^{\circ} \mathrm{C}$ in each experiment, except for $5 \mathbf{a}-\mathbf{i}$ where temperature was always maintained to $125{ }^{\circ} \mathrm{C}$.

\section{General procedure for synthesis of nitrones $4 a-0$ and $5 a-i$}

The selected ketone $(0.5 \mathrm{~g})$ and appropriate hydroxylamine derivative (2 eq. or 3 eq. for $N$-phenylhydroxylamine) were grinded in a mortar, placed in apposite vessel and mixed in a vortex. The mixture was transferred to a microwave oven and was irradiated with the opportune power. After the appropriate time the crude oil was recrystallized with ethyl acetate $(\mathbf{4 a - o})$ or cyclohexane (5a-i).

$(E)$ - $\boldsymbol{N}$-Methyl- $\boldsymbol{C}$-isatinyl nitrone 4a. Yellow solid, 97\% yield. ${ }^{1} \mathrm{H}$ NMR (300 MHz, DMSO-d $\left.{ }_{6}\right): \delta 4.28\left(\mathrm{~s}, 3 \mathrm{H}, \mathrm{CH}_{3}\right), 6.92(\mathrm{~d}, J=$ $7.74 \mathrm{~Hz}, 1 \mathrm{H}, \mathrm{Ar}), 7.06$ (t, $J=7.60 \mathrm{~Hz}, 1 \mathrm{H}, \mathrm{Ar}), 7.38(\mathrm{t}, J=7.60 \mathrm{~Hz}$, $1 \mathrm{H}, \mathrm{Ar}), 8.15$ (d, $J=7.74 \mathrm{~Hz}, 1 \mathrm{H}, \mathrm{Ar}), 10.90(\mathrm{~s}, 1 \mathrm{H}, \mathrm{NH}),{ }^{13} \mathrm{C} \mathrm{NMR}$ (75 MHz, DMSO-d ${ }_{6}$ ): $\delta$ 50.1, 109.1, 117.6, 121.3, 123.2, 130.9, 133.1, 138.9, 160.8. ESI(+)-MS calcd for $\mathrm{C}_{9} \mathrm{H}_{9} \mathrm{~N}_{2} \mathrm{O}_{2}[\mathrm{M}+\mathrm{H}]$ 177.0664, found: 177.0655 .

(E)-N-Benzyl- $\boldsymbol{C}$-isatinyl nitrone $4 \mathrm{~b}$. Orange solid, 95\% yield. ${ }^{1} \mathrm{H}$ NMR (300 MHz, DMSO-d ${ }_{6}$ ): $\delta 5.89\left(\mathrm{~s}, 2 \mathrm{H}, \mathrm{CH}_{2 \mathrm{Bn}}\right), 6.91(\mathrm{~d}, J=$ $7.78 \mathrm{~Hz}, 1 \mathrm{H}, \mathrm{Ar}), 7.10$ (dt, $J=0.91,7.65 \mathrm{~Hz}, 1 \mathrm{H}, \mathrm{Ar}), 7.25-7.54$ (m, 6H, Ar), 8.12 (d, $J=7.65 \mathrm{~Hz}, 1 \mathrm{H}, \mathrm{Ar}), 11.01(\mathrm{~s}, 1 \mathrm{H}, \mathrm{NH}),{ }^{13} \mathrm{C}$ NMR (75 MHz, DMSO-d ${ }_{6}$ ): $\delta$ 64.3, 109.8, 118.1, 122.04, 123.9, 
128.5, 129.6, 129.1, 131.8, 133.4, 134.2, 139.6, 161.2. ESI(+)-MS: $m / z[\mathrm{M}+\mathrm{H}]$ calcd for $\mathrm{C}_{15} \mathrm{H}_{13} \mathrm{~N}_{2} \mathrm{O}_{2}$ 253.0977, found: 253.0977 .

$(E)$ - $\boldsymbol{N}$-Phenyl- $\boldsymbol{C}$-isatinyl nitrone 4c. Orange red solid, $92 \%$ yield. ${ }^{1} \mathrm{H}$ NMR $\left(300 \mathrm{MHz}\right.$, DMSO-d $\left.{ }_{6}\right): \delta 6.85(\mathrm{~d}, J=7.80 \mathrm{~Hz}, 1 \mathrm{H}$, $\operatorname{Ar}$ ), 7.15 (t, $J=7.65 \mathrm{~Hz}, 1 \mathrm{H}, \operatorname{Ar}), 7.40$ (t, $J=7.80 \mathrm{~Hz}, 1 \mathrm{H}, \operatorname{Ar})$, 7.45-7.65 (m, 5H, Ar), 8.27 (d, $J=7.65 \mathrm{~Hz}, 1 \mathrm{H}, \mathrm{Ar}), 10.78$ (s, $1 \mathrm{H}$, $\mathrm{NH}),{ }^{13} \mathrm{C}$ NMR (75 MHz, DMSO-d 6 ): $\delta$ 109.7, 118.4, 121.7, 123.9, 124.1, 128.7, 130.1, 132.2, 134.4, 140.9, 146.3, 159.9. ESI(+)-MS: $m / z[\mathrm{M}+\mathrm{H}]$ calcd for $\mathrm{C}_{14} \mathrm{H}_{11} \mathrm{~N}_{2} \mathrm{O}_{2} 239.0821$, found: 239.0817 .

$(E)-N$-3-Cl-phenyl- $C$-isatinyl nitrone $4 d$ (the most abundant). Orange solid, 87\% yield. ${ }^{1} \mathrm{H}$ NMR (300 MHz, DMSO-d $\left.\mathrm{d}_{6}\right): \delta 6.35$ $(\mathrm{d}, J=7.71,1 \mathrm{H}, \mathrm{Ar}), 6.79(\mathrm{t}, J=7.71,1 \mathrm{H}, \mathrm{Ar}), 6.85-7.05(\mathrm{~m}, 2 \mathrm{H}$, $\mathrm{Ar}), 7.07-7.18(\mathrm{~m}, 1 \mathrm{H}, \mathrm{Ar}), 7.27-7.44(\mathrm{~m}, 2 \mathrm{H}, \mathrm{Ar}), 7.45-7.56(\mathrm{~m}$, $1 \mathrm{H}, \mathrm{Ar}), 11.04$ (s, 1H, NH), ${ }^{13} \mathrm{C}$ NMR (75 MHz, DMSO-d 6 ): $\delta$ 111.6, $115.6,116.1,117.1,121.9$, 124.6, 125.4, 131.4, 134.0, 134.6, 146.0, 150.8, 155.6, 163.3. ESI(+)-MS: $m / z[\mathrm{M}+\mathrm{H}]$ calcd for $\mathrm{C}_{14} \mathrm{H}_{10} \mathrm{ClN}_{2} \mathrm{O}_{2}$ 273.0431, found: $273.0422 ;[\mathrm{M}+\mathrm{H}]+2$ calcd for $\mathrm{C}_{14} \mathrm{H}_{10} \mathrm{ClN}_{2} \mathrm{O}_{2}$ 275.0401, found: 275.0382 .

$(E)-N$-Methyl- $C$-(1-methyl)-isatinyl nitrone 4e. Yellow solid, 90\% yield. ${ }^{1} \mathrm{H}$ NMR (300 $\mathrm{MHz}, \mathrm{CDCl}_{3}$ ): $\delta 3.27\left(\mathrm{~s}, 3 \mathrm{H}, \mathrm{CH}_{3}\right), 4.38$ $\left(\mathrm{s}, 3 \mathrm{H}, \mathrm{CH}_{3}\right), 6.82(\mathrm{~d}, J=7.83 \mathrm{~Hz}, 1 \mathrm{H}, \mathrm{Ar}), 7.09(\mathrm{t}, J=7.65 \mathrm{~Hz}, 1 \mathrm{H}$, $\mathrm{Ar}), 7.38$ (t, $J=7.83 \mathrm{~Hz}, 1 \mathrm{H}, \mathrm{Ar}), 8.30$ (d, $J=7.65 \mathrm{~Hz}, 1 \mathrm{H}, \mathrm{Ar}),{ }^{13} \mathrm{C}$ NMR (75 MHz, $\mathrm{CDCl}_{3}$ ): $\delta$ 26.0, 51.2, 107.6, 118.3, 123.0, 123.0, 124.8, 131.3, 141.2, 160.9. $\mathrm{ESI}(+)$-MS: $m / z[\mathrm{M}+\mathrm{H}]$ calcd for $\mathrm{C}_{10} \mathrm{H}_{11} \mathrm{~N}_{2} \mathrm{O}_{2}$ 191.0821, found: 191.0815.

$(E)-N$-Benzyl- $\boldsymbol{C}$-(1-methyl)-isatinyl nitrone 4f. Yellow solid, 92\% yield. ${ }^{1} \mathrm{H}$ NMR (300 MHz, DMSO-d $\left.\mathrm{d}_{6}\right): \delta 3.25\left(\mathrm{~s}, 3 \mathrm{H}, \mathrm{CH}_{3}\right)$, $5.92\left(\mathrm{~s}, 2 \mathrm{H}, \mathrm{CH}_{2}\right), 7.08(\mathrm{t}, J=8.26 \mathrm{~Hz}, 2 \mathrm{H}, \mathrm{Ar}), 7.37-7.50(\mathrm{~m}, 6 \mathrm{H}$, $\mathrm{Ar}), 8.15$ (d, $J=7.34 \mathrm{~Hz}, 1 \mathrm{H}, \mathrm{Ar}),{ }^{13} \mathrm{C}$ NMR (75 MHz DMSO-d 6 ): $\delta$ 26.6, 65.2, 109.2, 117.8, 123.1, 124.0, 129.0, 129.0, 129.59, 132.2, 134.6, 141.5, 160.4. $\mathrm{ESI}(+)-\mathrm{MS}: m / z[\mathrm{M}+\mathrm{H}]$ calcd for $\mathrm{C}_{16} \mathrm{H}_{15} \mathrm{~N}_{2} \mathrm{O}_{2}$ 267.1134, found: 267.1126.

(E)-N-Phenyl- $C$-(1-methyl)-isatinyl nitrone $4 \mathrm{~g}$. Orange solid, 90\% yield. ${ }^{1} \mathrm{H}$ NMR (300 MHz, DMSO-d $\left.{ }_{6}\right): \delta 3.11\left(\mathrm{~s}, 3 \mathrm{H}, \mathrm{CH}_{3}\right)$, 7.08-7.16 (m, 2H, Ar), 7.46-7.58 (m, 6H, Ar), 8.30 (d, J=7.48 Hz, $1 \mathrm{H}, \mathrm{Ar}),{ }^{13} \mathrm{C}$ NMR (75 MHz, DMSO-d 6 ): $\delta$ 26.5, 110.7, 115.4, 116.5 , 117.5, 122.8, 125.1, 125.5, 131.9, 134.4, 135.1, 148.5, 152.2, 155.3, 162.4. ESI(+)-MS: $m / z[\mathrm{M}+\mathrm{H}]$ calcd for $\mathrm{C}_{15} \mathrm{H}_{13} \mathrm{~N}_{2} \mathrm{O}_{2}$ 253.0977, found: 253.0975 .

$(E)-N$-3-Cl-phenyl- $C$-(1-methyl)-isatinyl nitrone $4 \mathrm{~h}$ (the most abundant). Yellow solid, 88\% yield. ${ }^{1} \mathrm{H}$ NMR (300 MHz, DMSO$\left.\mathrm{d}_{6}\right): \delta 3.21\left(\mathrm{~s}, 3 \mathrm{H}, \mathrm{CH}_{3}\right), 6.37-6.40(\mathrm{~m}, 1 \mathrm{H}, \mathrm{Ar}), 6.85-7.12(\mathrm{~m}, 4 \mathrm{H}$, $\mathrm{Ar}), 7.32-7.65$ (m, 3H, Ar), ${ }^{13} \mathrm{C}$ NMR (75 MHz, DMSO-d 6 ): $\delta 26.6$, $110.7,115.4,116.5,117.5,122.8,125.1,125.5$, 131.9, 134.4, 135.1, 148.5, 152.2, 155.3, 162.4. ESI(+)-MS: $m / z[\mathrm{M}+\mathrm{H}]$ calcd for $\mathrm{C}_{15} \mathrm{H}_{12} \mathrm{ClN}_{2} \mathrm{O}_{2}$ 287.0587, found: 287.0577; [M $\left.+\mathrm{H}\right]+2$ calcd for $\mathrm{C}_{15} \mathrm{H}_{12} \mathrm{ClN}_{2} \mathrm{O}_{2} 289.0558$, found: 289.0557 .

$(E)-N$-Methyl- $C$-(5-Br)-isatinyl nitrone 4i. Orange solid, 95\% yield. ${ }^{1} \mathrm{H}$ NMR (300 MHz, DMSO-d $\left.{ }_{6}\right): \delta 4.26\left(\mathrm{~s}, 3 \mathrm{H}, \mathrm{CH}_{3}\right), 6.83$ (d, $J=8.24 \mathrm{~Hz}, 1 \mathrm{H}, \mathrm{Ar}$ ), 7.50 (dd, $J=1.92 \mathrm{~Hz}, 8.24,1 \mathrm{H}, \mathrm{Ar}), 8.18$ (d, $J$ $=1.92 \mathrm{~Hz}, 1 \mathrm{H}, \mathrm{Ar}), 11.02(\mathrm{~s}, 1 \mathrm{H}, \mathrm{NH}),{ }^{13} \mathrm{C}$ NMR $(75 \mathrm{MHz}, \mathrm{DMSO}-$ $\left.\mathrm{d}_{6}\right): \delta 51.4,112.0,113.7,120.4,126.0,133.5,134.0,139.0,161.4$. ESI(+)-MS: $m / z[\mathrm{M}+\mathrm{H}]$ calcd for $\mathrm{C}_{9} \mathrm{H}_{8} \mathrm{BrN}_{2} \mathrm{O}_{2}$ 254.9769, found: 254.9762; $[\mathrm{M}+\mathrm{H}]+2$ calcd for $\mathrm{C}_{9} \mathrm{H}_{8} \mathrm{BrN}_{2} \mathrm{O}_{2}$ 256.9749, found: 256.9746 .

$(E)-N$-Benzyl- $C$-(5-Br)-isatinyl nitrone 4 j. Orange solid, $93 \%$ yield. ${ }^{1} \mathrm{H}$ NMR (300 MHz, DMSO-d $\left.{ }_{6}\right): \delta 5.89\left(\mathrm{~s}, 2 \mathrm{H}, \mathrm{CH}_{2}\right), 6.87$ (d,
$J=7.95 \mathrm{~Hz}, 1 \mathrm{H}, \mathrm{Ar}), 7.26-7.63(\mathrm{~m}, 6 \mathrm{H}, \mathrm{Ar}), 8.21$ (s, 1H, Ar), 11.16 $(\mathrm{s}, 1 \mathrm{H}, \mathrm{NH}){ }^{13} \mathrm{C}$ NMR $\left(75 \mathrm{MHz}, \mathrm{DMSO}-\mathrm{d}_{6}\right): \delta 65.2,112.2,113.9$, 120.5, 126.2, 129.0, 129.0, 129.5, 133.3, 134.4, 134.4, 139.2, 161.3. $\mathrm{ESI}(+)-\mathrm{MS}: m / z[\mathrm{M}+\mathrm{H}]$ calcd for $\mathrm{C}_{15} \mathrm{H}_{12} \mathrm{BrN}_{2} \mathrm{O}_{2} 331.0082$, found: $333.0071 ;[\mathrm{M}+\mathrm{H}]+2$ calcd for $\mathrm{C}_{15} \mathrm{H}_{12} \mathrm{BrN}_{2} \mathrm{O}_{2}$ 333.0062, found: 333.0053 .

$(E)-N$-Phenyl- $C$-(5-Br)-isatinyl nitrone $4 \mathbf{k}$. Orange solid, $92 \%$ yield. ${ }^{1} \mathrm{H}$ NMR (300 MHz, DMSO-d $\left.{ }_{6}\right): \delta 6.86(\mathrm{dd}, J=2.93 \mathrm{~Hz}$, $8.25 \mathrm{~Hz}, 1 \mathrm{H}, \mathrm{Ar}$ ), $7.40-7.77$ (m, 6H, Ar), 8.37 (d, $J=1.83 \mathrm{~Hz}, 1 \mathrm{H}$, Ar), $10.92(\mathrm{~s}, 1 \mathrm{H}, \mathrm{NH}){ }^{13} \mathrm{C}$ NMR $\left(75 \mathrm{MHz}, \mathrm{DMSO}-\mathrm{d}_{6}\right): \delta 116.9$, 118.4, 125.6, 129.1, 131.2, 134.0, 135.7, 135.8, 139.6, 145.3, 151.4, 164.8. $\mathrm{ESI}(+)-\mathrm{MS}: \mathrm{m} / z[\mathrm{M}+\mathrm{H}]$ calcd for $\mathrm{C}_{14} \mathrm{H}_{10} \mathrm{BrN}_{2} \mathrm{O}_{2}$ 316.9932, found: 316.9919; $[\mathrm{M}+\mathrm{H}]+2$ calcd for $\mathrm{C}_{14} \mathrm{H}_{10} \mathrm{BrN}_{2} \mathrm{O}_{2}$ 318.9905, found: 318.9899.

(E)-N-Methyl- $\mathrm{C}$-(5-NO $\left.\mathrm{N}_{2}\right)$-isatinyl nitrone 41. Yellow solid, 95\% yield. ${ }^{1} \mathrm{H}$ NMR (300 MHz, DMSO-d ${ }_{6}$ ): $\delta 4.28$ (s, 3H, $\mathrm{CH}_{3}$ ), 7.02 (d, $J=8.73 \mathrm{~Hz}, 1 \mathrm{H}, \mathrm{Ar}$ ), 8.23 (d, $J=8.73 \mathrm{~Hz}, 1 \mathrm{H}, \mathrm{Ar}), 8.75$ (s, 1H, Ar), $11.53(\mathrm{~s}, 1 \mathrm{H}, \mathrm{NH}){ }^{13} \mathrm{C}$ NMR $\left(75 \mathrm{MHz}, \mathrm{DMSO}_{-} \mathrm{d}_{6}\right): \delta 51.8,110.2$, 118.7, 118.7, 128.0, 133.3, 142.4, 145.2, 161.9. ESI(+)-MS: $m / z$ [M $+\mathrm{H}$ ] calcd for $\mathrm{C}_{9} \mathrm{H}_{8} \mathrm{~N}_{3} \mathrm{O}_{4} 222.0515$, found: 222.0503 .

$(E)-N$-Benzyl- $C$ - $\left(5-\mathrm{NO}_{2}\right)$-isatinyl nitrone 4m. Yellow solid, 92\% yield. ${ }^{1} \mathrm{H}$ NMR (300 MHz, DMSO-d $\left.{ }_{6}\right): \delta 5.91\left(\mathrm{~s}, 2 \mathrm{H}, \mathrm{CH}_{2}\right)$, 7.07 (d, $J=8.73 \mathrm{~Hz}, 1 \mathrm{H}, \mathrm{Ar}), 7.31-7.58$ (m, 5H, Ar), 8.28 (dd, $J=$ $2.43 \mathrm{~Hz}, 8.73 \mathrm{~Hz}, 1 \mathrm{H}, \mathrm{Ar}), 8.84$ (d, $J=2.43 \mathrm{~Hz}, 1 \mathrm{H}, \mathrm{Ar}), 11.70$ (s, $1 \mathrm{H}, \mathrm{NH}){ }^{13} \mathrm{C}$ NMR $\left(75 \mathrm{MHz}, \mathrm{DMSO}-\mathrm{d}_{6}\right): \delta 65.6,110.4,118.8$, 119.0, 128.3, 129.1, 129.1, 129.6, 133.2, 134.1, 142.6, 145.4,

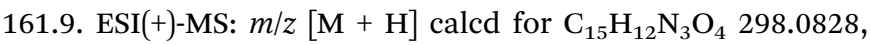
found: 298.0816 .

$(E)-N$-Phenyl- $C$-(5-NO $\mathrm{NO}_{2}$-isatinyl nitrone 4n. Dark yellow solid, 92\% yield. ${ }^{1} \mathrm{H}$ NMR $\left(300 \mathrm{MHz}, \mathrm{DMSO}-\mathrm{d}_{6}\right): \delta 7.06(\mathrm{~d}, J=8.79 \mathrm{~Hz}$, $1 \mathrm{H}, \mathrm{Ar}$ ), $7.46-7.69$ (m, 5H, Ar), 8.33 (dd, $J=2.37 \mathrm{~Hz}, 8.79 \mathrm{~Hz}, 1 \mathrm{H}$, $\mathrm{Ar}$ ), 9.00 (d, $J=1.83 \mathrm{~Hz}, 1 \mathrm{H}, \mathrm{Ar}), 11.47$ (s, 1H, NH) ${ }^{13} \mathrm{C} \mathrm{NMR}(75$ MHz, DMSO-d $\left.{ }_{6}\right): \delta 110.3,119.2,124.4,128.8,129.8,131.2,134.2$, 142.4, 146.5, 146.7, 160.6. $\mathrm{ESI}(+)-\mathrm{MS}: m / z[\mathrm{M}+\mathrm{H}]$ calcd for $\mathrm{C}_{14} \mathrm{H}_{10} \mathrm{~N}_{3} \mathrm{O}_{4}$ 284.0671, found: 284.0662.

(E)- $N$-Methyl- $C$-(5,7-Cl)-isatinyl nitrone 4o. Orange solid, $80 \%$ yield. ${ }^{1} \mathrm{H}$ NMR (300 MHz, DMSO-d $\left.{ }_{6}\right): \delta 4.25\left(\mathrm{~s}, 3 \mathrm{H}, \mathrm{CH}_{3}\right)$, 7.47 (d, $J=2.01 \mathrm{~Hz}, 1 \mathrm{H}, \mathrm{Ar}), 7.91$ (d, $J=2.01 \mathrm{~Hz}, 1 \mathrm{H}, \mathrm{Ar}$ ), 11.37 $(\mathrm{s}, 1 \mathrm{H}, \mathrm{NH}),{ }^{13} \mathrm{C}$ NMR (75 MHz, DMSO-d 6 ): $\delta$ 51.8, 115.0, 121.0, 121.8, 126.6, 130.2, 133.5, 136.2, 161.4. $\mathrm{ESI}(+)-\mathrm{MS}: m / z[\mathrm{M}+\mathrm{H}]$ calcd for $\mathrm{C}_{9} \mathrm{H}_{7} \mathrm{Cl}_{2} \mathrm{~N}_{2} \mathrm{O}_{2}$ 244.9885, found: 244.9878 ; $[\mathrm{M}+\mathrm{H}]+2$ calcd for $\mathrm{C}_{9} \mathrm{H}_{7} \mathrm{Cl}_{2} \mathrm{~N}_{2} \mathrm{O}_{2}$ 246.9855, found: $246.9849 ;[\mathrm{M}+\mathrm{H}]+4$ calcd for $\mathrm{C}_{9} \mathrm{H}_{7} \mathrm{Cl}_{2} \mathrm{~N}_{2} \mathrm{O}_{2}$ 248.9826, found: 248.9820 .

$(Z)-N$-Methyl- $C$-indanyl nitrone 5 a. White solid, $82 \%$ yield. ${ }^{1} \mathrm{H}$ NMR (300 MHz, $\mathrm{CDCl}_{3}$ ): $\delta$ 2.90-3.05 (m, 2H, $\mathrm{CH}_{2}$ ), 3.11-3.22 $\left(\mathrm{m}, 2 \mathrm{H}, \mathrm{CH}_{2}\right), 3.81\left(\mathrm{~s}, 3 \mathrm{H}, \mathrm{CH}_{3}\right), 7.29-7.44(\mathrm{~m}, 3 \mathrm{H}, \mathrm{Ar}), 8.84(\mathrm{~d}, J$ $=7.81 \mathrm{~Hz}, 1 \mathrm{H}, \mathrm{Ar}),{ }^{13} \mathrm{C} \mathrm{NMR}\left(75 \mathrm{MHz}, \mathrm{CDCl}_{3}\right): \delta 28.7,29.4,49.6$, 124.5, 127.0, 131.0, 134.4, 147.8, 149.7. $\mathrm{ESI}(+)-\mathrm{MS}: m / z[\mathrm{M}+\mathrm{H}]$ calcd for $\mathrm{C}_{10} \mathrm{H}_{12} \mathrm{NO} 162.0919$, found: 162.0912 .

(Z)- $N$-Benzyl- $C$-indanyl nitrone $5 \mathbf{b}$. White solid, $85 \%$ yield. ${ }^{1} \mathrm{H}$ NMR (300 MHz, $\left.\mathrm{CDCl}_{3}\right): \delta 2.91-3.09\left(\mathrm{~m}, 2 \mathrm{H}, \mathrm{CH}_{2}\right), 3.10-3.23(\mathrm{~m}$, $\left.2 \mathrm{H}, \mathrm{CH}_{2}\right), 5.11$ (s, 2H, $\mathrm{CH}_{2 \mathrm{Bn}}$ ), 7.21-7.45 (m, 7H, Ar), 7.51 (d, $J=$ $7.16 \mathrm{~Hz}, 1 \mathrm{H}, \mathrm{Ar}), 8.92$ (d, $J=7.63 \mathrm{~Hz}, 1 \mathrm{H}, \mathrm{Ar}),{ }^{13} \mathrm{C} \mathrm{NMR}(75 \mathrm{MHz}$, $\left.\mathrm{CDCl}_{3}\right): \delta 29.0,29.2,66.6,124.5,127.1,127.2,128.2,128.3$, 128.9, 131.1, 133.4 134.8, 147.7, 149.1. $\mathrm{ESI}(+)-\mathrm{MS}: m / z[\mathrm{M}+\mathrm{H}]$ calcd for $\mathrm{C}_{16} \mathrm{H}_{16} \mathrm{NO} 238.1232$, found: 238.1230 . 
(Z)-N-Methyl-C-(2-Me)-indanyl nitrone 5c. White solid, $61 \%$ yield. ${ }^{1} \mathrm{H}$ NMR $\left(300 \mathrm{MHz}, \mathrm{CDCl}_{3}\right): \delta 1.28(\mathrm{~d}, J=6.99 \mathrm{~Hz}, 3 \mathrm{H}$, $\mathrm{CH}_{3}$ ), $2.70\left(\mathrm{~d}, J=16.5 \mathrm{~Hz}, 1 \mathrm{H}, \mathrm{H}_{\mathrm{CH}_{2}}\right), 3.20-3.50(\mathrm{~m}, 2 \mathrm{H}, \mathrm{CH}+$ $\left.\mathrm{H}_{\mathrm{CH}_{2}}\right), 3.85\left(\mathrm{~s}, 3 \mathrm{H}, \mathrm{CH}_{3}\right), 7.22-7.48(\mathrm{~m}, 3 \mathrm{H}, \mathrm{Ar}), 8.83(\mathrm{~d}, J=$ $7.53 \mathrm{~Hz}, 1 \mathrm{H}, \mathrm{Ar}),{ }^{13} \mathrm{C} \mathrm{NMR}\left(75 \mathrm{MHz}, \mathrm{CDCl}_{3}\right.$ ): $\delta$ 19.7, 36.4, 38.4, 48.9, 124.7, 127.1, 127.5, 131.1, 133.5, 145.9, 153.8. ESI(+)-MS: $m / z[\mathrm{M}+\mathrm{H}]$ calcd for $\mathrm{C}_{11} \mathrm{H}_{14} \mathrm{NO} 176.1075$, found: 176.1068 .

(Z)-N-Methyl-C-(3-Me)-indanyl nitrone 5d. White solid, $78 \%$ yield. ${ }^{1} \mathrm{H}$ NMR $\left(300 \mathrm{MHz}, \mathrm{CDCl}_{3}\right): \delta 1.38(\mathrm{~d}, 3 \mathrm{H}, J=7.02 \mathrm{~Hz}$, $\mathrm{CH}_{3}$ ), 2.53 (dd, $1 \mathrm{H}, J=2.79 \mathrm{~Hz}, 17.76 \mathrm{~Hz}, \mathrm{H}_{\mathrm{CH}_{2}}$ ), 3.24 (dd, $1 \mathrm{H}, J=$ $\left.7.29 \mathrm{~Hz}, 17.76 \mathrm{~Hz}, \mathrm{H}_{\mathrm{CH}_{2}}\right), 3.40-3.58(\mathrm{~m}, 1 \mathrm{H}, \mathrm{CH}), 3.78(\mathrm{~s}, 3 \mathrm{H}$, $\mathrm{CH}_{3}$ ), 7.28-7.51 (m, 3H, Ar), 8.83 (d, $\left.J=7.68 \mathrm{~Hz}, 1 \mathrm{H}, \mathrm{Ar}\right),{ }^{13} \mathrm{C}$ NMR (75 MHz, $\mathrm{CDCl}_{3}$ ): $\delta$ 21.7, 35.9, 38.8, 49.8, 123.5, 126.9, 127.3, 131.2, 133.8, 152.6. $\mathrm{ESI}(+)-\mathrm{MS}: m / z[\mathrm{M}+\mathrm{H}]$ calcd for $\mathrm{C}_{11} \mathrm{H}_{14} \mathrm{NO} 176.1075$, found: 176.1071 .

(Z)-N-Methyl- $C$-(2-Pr)-indanyl nitrone 5e. White solid, $20 \%$ yield. ${ }^{1} \mathrm{H} \mathrm{NMR}\left(300 \mathrm{MHz}, \mathrm{CDCl}_{3}\right): \delta 0.90\left(\mathrm{t}, 3 \mathrm{H}, J=6.47 \mathrm{~Hz}, \mathrm{CH}_{3}\right)$, 1.25-155 (m, 4H, $\left.\mathrm{CH}_{2}\right), 2.90-3.42\left(\mathrm{~m}, 3 \mathrm{H}, \mathrm{CH}+\mathrm{CH}_{2}\right), 3.83(\mathrm{~s}, 3 \mathrm{H}$, $\mathrm{CH}_{3}$ ), 7.18-7.49 (m, 3H, Ar), 8.79 (d, $\left.J=7.51 \mathrm{~Hz}, 1 \mathrm{H}, \mathrm{Ar}\right),{ }^{13} \mathrm{C}$ NMR (75 MHz, $\mathrm{CDCl}_{3}$ ): $\delta$ 13.8, 20.0, 35.7, 35.9, 41.6, 48.8, 124.7, 127.0, 127.5, 131.3, 134.0, 134.5, 146.7. ESI(+)-MS: $m / z[\mathrm{M}+\mathrm{H}]$ calcd for $\mathrm{C}_{13} \mathrm{H}_{18} \mathrm{NO} 204.1388$, found: 204.1384.

(Z)-N-Methyl-C-(5-Br)-indanyl nitrone 5 f. White solid, $88 \%$ yield. ${ }^{1} \mathrm{H} \mathrm{NMR}\left(300 \mathrm{MHz}, \mathrm{CDCl}_{3}\right.$ ): $\delta 3.0$ (dd, $J=5.55 \mathrm{~Hz}$, $12.03 \mathrm{~Hz}, 2 \mathrm{H}, \mathrm{CH}_{2}$ ), 3.14 (dd, $J=5.55 \mathrm{~Hz}, 12.51 \mathrm{~Hz}, 2 \mathrm{H}, \mathrm{CH}_{2}$ ), 3.81 (s, 3H, $\mathrm{CH}_{3}$ ), 7.29-7.44 (m, 3H, Ar), 8.84 (d, $J=7.81 \mathrm{~Hz}, 1 \mathrm{H}$, $\mathrm{Ar}),{ }^{13} \mathrm{C} \mathrm{NMR}\left(75 \mathrm{MHz}, \mathrm{CDCl}_{3}\right): \delta 28.6,29.5,49.9,125.1,127.8$, 128.0, 130.4 133.6, 148.1, 149.4. ESI(+)-MS: $m / z[\mathrm{M}+\mathrm{H}]$ calcd for $\mathrm{C}_{10} \mathrm{H}_{11}$ BrNO 240.0024, found: 240.0020 ; $[\mathrm{M}+\mathrm{H}]+2$ calcd for $\mathrm{C}_{10} \mathrm{H}_{11}$ BrNO 242.0004, found: 242.0000 .

(Z)-N-Methyl- $C$-(5-F)-indanyl nitrone $5 \mathrm{~g}$. White solid, $83 \%$ yield. ${ }^{1} \mathrm{H}$ NMR $\left(300 \mathrm{MHz}, \mathrm{CDCl}_{3}\right): \delta 3.01(\mathrm{dd}, J=5.43 \mathrm{~Hz}$, $\left.11.73 \mathrm{~Hz}, 2 \mathrm{H}, \mathrm{CH}_{2}\right), 3.14\left(\mathrm{dd}, J=5.55 \mathrm{~Hz}, 11.97 \mathrm{~Hz}, 2 \mathrm{H}, \mathrm{CH}_{2}\right.$ ), 6.80-7.12 (m, 2H, Ar), $8.86(\mathrm{dd}, J=5.79 \mathrm{~Hz}, 8.64 \mathrm{~Hz}, 1 \mathrm{H}, \mathrm{Ar}),{ }^{13} \mathrm{C}$ NMR (75 MHz, $\left.\mathrm{CDCl}_{3}\right): \delta 28.8\left(\mathrm{~d}, J_{\mathrm{CF}}=2.28\right), 29.9,49.6,111.9(\mathrm{~d}$, $\left.J^{2}{ }_{\mathrm{CF}}=23.02\right), 114.3\left(\mathrm{~d}, J^{2}{ }_{\mathrm{CF}}=22.86\right), 128.8\left(\mathrm{~d}, J^{3}{ }_{\mathrm{CF}}=9.03\right), 130.9$ $\left(\mathrm{d}, J_{\mathrm{CF}}^{4}=2.02\right), 148.1,150.5\left(\mathrm{~d}, J_{\mathrm{CF}}^{3}=8.95\right), 164.43\left(\mathrm{~d}, J_{\mathrm{CF}}^{1}=\right.$ 250.96). $\operatorname{ESI}(+)-M S: ~ m / z[M+\mathrm{H}]$ calcd for $\mathrm{C}_{10} \mathrm{H}_{11}$ FNO 180.0825, found: 180.0818 .

(Z)-N-Methyl- $C$-(4-Br-7-OH)-indanyl nitrone $5 \mathrm{~h}$. Yellow solid, $67 \%$ yield. ${ }^{1} \mathrm{H}$ NMR $\left(300 \mathrm{MHz}, \mathrm{CDCl}_{3}\right): \delta 2.86-2.95\left(\mathrm{~m}, 2 \mathrm{H}, \mathrm{CH}_{2}\right)$, 2.96-3.30 (m, 2H, $\left.\mathrm{CH}_{2}\right), 3.70\left(\mathrm{~s}, 3 \mathrm{H}, \mathrm{CH}_{3}\right), 6.60(\mathrm{~d}, 1 \mathrm{H}, J=$ $8.79 \mathrm{~Hz}, \mathrm{Ar}$ ), 7.37 (d, $J=8.79 \mathrm{~Hz}, 1 \mathrm{H}, \mathrm{Ar}), 14.96$ (s, $1 \mathrm{H}, \mathrm{OH}),{ }^{13} \mathrm{C}$ NMR (75 MHz, $\mathrm{CDCl}_{3}$ ): $\delta$ 30.2, 47.8, 107.2, 118.5, 121.2, 138.0, 149.6, 155.4, 157.9. ESI(+)-MS: $m / z[\mathrm{M}+\mathrm{H}]$ calcd for $\mathrm{C}_{10} \mathrm{H}_{11} \mathrm{BrNO}_{2}$ 255.9973, found: 255.9964; $[\mathrm{M}+\mathrm{H}]+2$ calcd for $\mathrm{C}_{10} \mathrm{H}_{11} \mathrm{BrNO}_{2}$ 255.9953, found: 255.9945.

(Z)-N-Benzyl-C-(4-Br-7-OH)-indanyl nitrone 5i. Pale yellow solid, 78\% yield. ${ }^{1} \mathrm{H}$ NMR (300 MHz, $\left.\mathrm{CDCl}_{3}\right): \delta 2.97\left(\mathrm{~s}, 4 \mathrm{H}, \mathrm{CH}_{2}\right)$, $5.04\left(\mathrm{~s}, 2 \mathrm{H}, \mathrm{CH}_{2}\right), 6.62(\mathrm{~d}, 1 \mathrm{H}, J=8.79 \mathrm{~Hz}, \mathrm{Ar}), 7.35-7.50(\mathrm{~m}, 6 \mathrm{H}$, $\mathrm{Ar}), 15.02(\mathrm{~s}, 1 \mathrm{H}, \mathrm{OH}),{ }^{13} \mathrm{C} \mathrm{NMR}\left(75 \mathrm{MHz}, \mathrm{CDCl}_{3}\right): \delta 29.8,30.2$, 64.6, 107.1, 118.6, 121.3, 127.9, 128.8, 129.1, 132.4, 138.0, 149.6, 155.5, 158.1. $\mathrm{ESI}(+)-\mathrm{MS}: m / z[\mathrm{M}+\mathrm{H}]$ calcd for $\mathrm{C}_{16} \mathrm{H}_{15} \mathrm{BrNO}_{2}$ 332.0286, found: 332.0276; $[\mathrm{M}+\mathrm{H}]+2$ calcd for $\mathrm{C}_{16} \mathrm{H}_{15} \mathrm{BrNO}_{2}$ 334.0266, found 334.0259:
General procedure for synthesis of nucleobase-containing spiro-isoxazolidines $7 \mathbf{a}-\mathbf{h}$ and $8 \mathrm{a}-\mathrm{b}$

The opportune nitrone (2 eq.) and $N$-1-vinylthymine $6 \mathbf{a}$ or $N$-1vinyluracil 6b $(0.05 \mathrm{~g})$ were grinded in a mortar, placed in apposite vessel and mixed in a vortex. The mixture was transferred to a microwave oven and was irradiated with the opportune power and temperature (when required). After the appropriate time the crude oil was purified by flash chromatography with hexane : AcOEt $7.75: 2.25 \mathrm{v} / \mathrm{v}$ for $7 \mathbf{c}-\mathbf{e}$ or $\mathrm{CHCl}_{3}$ / $\mathrm{MeOH} 9.75: 0.25 \mathrm{v} / \mathrm{v}$ for all the other crudes.

exo-5'-Thyminyl-2' -methyl-spiro-[indoline-3, $3^{\prime}$-isoxazolidine]1-methyl-2-one 7a. Red solid, 85\% yield. ${ }^{1} \mathrm{H}$ NMR $(500 \mathrm{MHz}$, $\left.\mathrm{CDCl}_{3}\right): \delta 2.02\left(\mathrm{~d}, J=1.21,3 \mathrm{H}, \mathrm{CH}_{3}\right), 2.57\left(\mathrm{~s}, 3 \mathrm{H}, \mathrm{CH}_{3}\right), 2.64(\mathrm{dd}, J$ $\left.=4.31 \mathrm{~Hz}, 14.03 \mathrm{~Hz}, 1 \mathrm{H}, \mathrm{H}_{\mathrm{CH}_{2}}\right), 3.22\left(\mathrm{~s}, 3 \mathrm{H}, \mathrm{CH}_{3}\right), 3.28(\mathrm{dd}, J=$ $\left.7.48 \mathrm{~Hz}, 14.03 \mathrm{~Hz}, 1 \mathrm{H}, \mathrm{H}_{\mathrm{CH}_{2}}\right), 6.44(\mathrm{dd}, J=4.31 \mathrm{~Hz}, 7.48 \mathrm{~Hz}, 1 \mathrm{H}$, $\mathrm{CH}), 6.86$ (d, J=7.85 Hz, 1H, Ar), 7.09-7.14 (m, 1H, Ar), 7.24-7.29 (m, 1H, Ar), 7.36-7.41 (m, 1H, Ar), 7.77 (d, $J=1.21 \mathrm{~Hz}, 1 \mathrm{H}, 6-$ $\left.\mathrm{CH}_{\text {Thy }}\right), 8.65\left(\mathrm{~s}_{\mathrm{b}}, 1 \mathrm{H}, \mathrm{NH}_{\text {Thy }}\right){ }^{13} \mathrm{C} \mathrm{NMR}\left(125 \mathrm{MHz} \mathrm{CDCl}_{3}\right): \delta 12.8$, 26.0, 38,0, 47.6, 72.3, 83.4, 108.6, 110.7, 123.3, 123.3, 124.1, 130.5, 135.3, 144.2, 150.2, 163.8, 173.9. $\mathrm{ESI}(+)-\mathrm{MS}: m / z[\mathrm{M}+\mathrm{H}]$ calcd for $\mathrm{C}_{17} \mathrm{H}_{19} \mathrm{~N}_{4} \mathrm{O}_{4}$ 343.1406, found: 343.1403.

exo-5'-Uracil-2' -benzyl-spiro-[indoline-3,3'-isoxazolidine]-2one 7b. Yellow solid, 85\% yield. ${ }^{1} \mathrm{H}$ NMR (300 MHz, DMSO- $\mathrm{d}_{6}$ ):

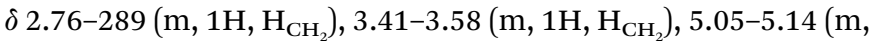
$\left.2 \mathrm{H}, \mathrm{CH}_{2 \mathrm{Bn}}\right), 5.59(\mathrm{dd}, J=2.20 \mathrm{~Hz}, 7.95 \mathrm{~Hz}, 1 \mathrm{H}, \mathrm{CH}), 6.68(\mathrm{~d}, J=$ $\left.7.68 \mathrm{~Hz}, 1 \mathrm{H}, 5-\mathrm{CH}_{\mathrm{Ura}}\right), 6.75-7.92(\mathrm{~m}, 9 \mathrm{H}, \mathrm{Ar}), 7.97$ (d, $J=7.68$, $\left.1 \mathrm{H}, 6-\mathrm{CH}_{\text {Ura }}\right), 10.23\left(\mathrm{~s}_{\mathrm{b}}, 1 \mathrm{H}, \mathrm{NH}\right), 11.05\left(\mathrm{~s}_{\mathrm{b}}, 1 \mathrm{H}, \mathrm{NH}_{\mathrm{Ura}}\right) .{ }^{13} \mathrm{C} \mathrm{NMR}$ (75 MHz, DMSO-d 6 ): $\delta$ 61,4, 72.6, 101.2, 109.9, 122.0, 125.3, 127.1 , 127.3, 128.1, 128.4, 128.9, 129.5, 130.2, 142.8, 143.4, 151.2, 163.1, 168.5, 180.2. $\mathrm{ESI}(+)-\mathrm{MS}: m / z[\mathrm{M}+\mathrm{H}]$ calcd for $\mathrm{C}_{21} \mathrm{H}_{19} \mathrm{NaN}_{4} \mathrm{O}_{4} 413.1226$, found: 413.1219 .

exo-5'-Uracil-2' -phenyl-spiro-[indoline-3, $3^{\prime}$-isoxazolidine]-2one 7c. Orange solid, $84 \%$ yield. ${ }^{1} \mathrm{H}$ NMR (300 MHz, DMSO- $\left.\mathrm{d}_{6}\right)$ : $\delta 2.98-3.11\left(\mathrm{~m}, 1 \mathrm{H}, \mathrm{H}_{\mathrm{CH}_{2}}\right), 3.25-3.33\left(\mathrm{~m}, 1 \mathrm{H}, \mathrm{H}_{\mathrm{CH}_{2}}\right), 5.79(\mathrm{~d}, J=$ $\left.8.07 \mathrm{~Hz}, 1 \mathrm{H}, 5-\mathrm{CH}_{\mathrm{Ura}}\right), 6.24(\mathrm{dd}, J=5.31 \mathrm{~Hz}, 7.14 \mathrm{~Hz}, 1 \mathrm{H}, \mathrm{CH})$, 6.65-7.66 (m, 8H, Ar), 7.98 (d, $J=8.28 \mathrm{~Hz}, 1 \mathrm{H}, \mathrm{Ar}), 8.55$ (d, $J=$ $\left.8.07 \mathrm{~Hz}, 1 \mathrm{H}, 6-\mathrm{CH}_{\mathrm{Ura}}\right), 10.43\left(\mathrm{~s}_{\mathrm{b}}, 1 \mathrm{H}, \mathrm{NH}\right), 10.89\left(\mathrm{~s}_{\mathrm{b}}, 1 \mathrm{H}\right.$, $\left.\mathrm{NH}_{\text {Ura }}\right) .{ }^{13} \mathrm{C}$ NMR (75 MHz, DMSO-d 6 ): $\delta$ 46.8, 72.9, 80.9, 102.6, 110.5 , 118.1, 124.4, 126.1, 128.8, 128.9, 128.2, 130.9, 132.7, 141.8, 145.6, 151.4, 163.4, 175.6. ESI(+)-MS: $m / z[\mathrm{M}+\mathrm{H}]$ calcd for $\mathrm{C}_{20} \mathrm{H}_{17} \mathrm{~N}_{4} \mathrm{O}_{4}$ 377.1250, found: 377.1237 .

exo-5' -Thyminyl-2' -phenyl-spiro-[indoline-3, $3^{\prime}$-isoxazolidine]2-one 7d. Orange solid, 85\% yield. ${ }^{1} \mathrm{H}$ NMR (300 MHz, DMSO$\left.\mathrm{d}_{6}\right): \delta 1.89\left(\mathrm{~s}, 3 \mathrm{H}, \mathrm{CH}_{3}\right) 2.99-3.14\left(\mathrm{~m}, 1 \mathrm{H}, \mathrm{H}_{\mathrm{CH}_{2}}\right), 3.16-3.32(\mathrm{~m}$, $\left.1 \mathrm{H}, \mathrm{H}_{\mathrm{CH}_{2}}\right), 6.67-7.58(\mathrm{~m}, 10 \mathrm{H}, \mathrm{Ar}+\mathrm{CH}), 8.53\left(\mathrm{~s}, 1 \mathrm{H}, 6-\mathrm{CH}_{\mathrm{Thy}}\right)$, $10.46\left(\mathrm{~s}_{\mathrm{b}}, 1 \mathrm{H}, \mathrm{NH}\right), 11.48\left(\mathrm{~s}_{\mathrm{b}}, 1 \mathrm{H}, \mathrm{NH}_{\mathrm{Thy}}\right) .{ }^{13} \mathrm{C} \mathrm{NMR}(75 \mathrm{MHz}$, DMSO- $\left.\mathrm{d}_{6}\right): \delta 12.8,45.0,73.5,81.8,100.3,110.8,117.3,118.0$, 122.8 , 124.6, 128.8, 128.9, 130.9, 135.7, 142.8, 146.4, 151.1, 164.0, 175.8. $\mathrm{ESI}(+)-\mathrm{MS}: \mathrm{m} / z[\mathrm{M}+\mathrm{H}]$ calcd for $\mathrm{C}_{21} \mathrm{H}_{19} \mathrm{~N}_{4} \mathrm{O}_{4}$ 391.1406, found: 391.1402 .

exo-5'-Uracil-2'-methyl-spiro-[indoline-3, $3^{\prime}$-isoxazolidine]-1methyl-2-one 7e. Orange solid, 84\% yield. ${ }^{1} \mathrm{H}$ NMR $(300 \mathrm{MHz}$, DMSO-d $\left.{ }_{6}\right): \delta 2.42\left(\mathrm{~s}, 3 \mathrm{H}, \mathrm{CH}_{3}\right), 2.82(\mathrm{dd}, J=4.86 \mathrm{~Hz}, 13.98 \mathrm{~Hz}$, $\left.1 \mathrm{H}, \mathrm{H}_{\mathrm{CH}_{2}}\right), 3.05-3.22\left(\mathrm{~m}, 4 \mathrm{H}, \mathrm{CH}_{3}+\mathrm{H}_{\mathrm{CH}_{2}}\right), 6.34(\mathrm{dd}, J=4.86 \mathrm{~Hz}$, $7.47 \mathrm{~Hz}, 1 \mathrm{H}, \mathrm{CH}), 7.00-7.21$ (m, 2H, Ar), 7.38-7.55 (m, 2H, Ar), $7.98\left(\mathrm{~d}, J=8.16,1 \mathrm{H}, 5-\mathrm{CH}_{\mathrm{Ura}}\right), 8.03\left(\mathrm{~d}, J=8.16 \mathrm{~Hz}, 1 \mathrm{H}, 6-\mathrm{CH}_{\text {Ura }}\right)$, 
$11.46\left(\mathrm{~s}_{\mathrm{b}}, 1 \mathrm{H}, \mathrm{NH}_{\mathrm{Ura}}\right) .{ }^{13} \mathrm{C}$ NMR (75 MHz, DMSO-d 6 ): $\delta 26.3,38,1$, 46.3, 72.5, 82.6, 108.9, 109.5, 123.2, 124.9, 129.9, 130.7, 140.1, 144.7, 151.0, 163.7, 173.9. ESI(+)-MS: $m / z[\mathrm{M}+\mathrm{H}]$ calcd for $\mathrm{C}_{16} \mathrm{H}_{16} \mathrm{~N}_{4} \mathrm{O}_{4} 329.1250$, found: 329.1242 .

exo-5' -Thyminyl-2' -methyl-spiro-[5-bromo-indoline-3, $\mathbf{3}^{\prime}$ isoxazolidine]-2-one $7 f$. Yellow solid, 77\% yield. ${ }^{1} \mathrm{H}$ NMR (500 MHz, DMSO-d $\left.\mathrm{d}_{6}\right): \delta 1.92\left(\mathrm{~s}, 3 \mathrm{H}, \mathrm{CH}_{3}\right), 2.97(\mathrm{dd}, J=6.04 \mathrm{~Hz}$, $13.73 \mathrm{~Hz}, 1 \mathrm{H}, \mathrm{H}_{\mathrm{CH}_{2}}$ ), 3.46 (dd, $J=7.14 \mathrm{~Hz}, 13.73 \mathrm{~Hz}, 1 \mathrm{H}, \mathrm{H}_{\mathrm{CH}_{2}}$ ), $3.54\left(\mathrm{~s}, 3 \mathrm{H}, \mathrm{NCH}_{3}\right), 6.40$ (dd, $\left.J=6.04 \mathrm{~Hz}, 7.14 \mathrm{~Hz}, 1 \mathrm{H}, \mathrm{CH}\right), 6.85$ (d, $J=8.23 \mathrm{~Hz}, 1 \mathrm{H}, \mathrm{Ar}), 7.18-7.56(\mathrm{~m}, 2 \mathrm{H}, \mathrm{Ar}), 7.72-7.81(\mathrm{~m}, 2 \mathrm{H}$, $\left.\mathrm{Ar}+6-\mathrm{CH}_{\text {Thy }}\right), 10.78\left(\mathrm{~s}_{\mathrm{b}}, 1 \mathrm{H}, \mathrm{NH}\right), 11.38\left(\mathrm{~s}_{\mathrm{b}}, 1 \mathrm{H}, \mathrm{NH}_{\mathrm{Thy}}\right){ }^{13} \mathrm{C} \mathrm{NMR}$ (125 MHz, DMSO-d ${ }_{6}$ ): $\delta$ 16.7, 33.3, 42.4, 74.2, 86.3, 114.1, 116.3, 118.1, 129.9, 130.9, 137.2, 140.0, 146.5, 154.9, 168.2, 179.3. ESI(+)-MS: $m / z[\mathrm{M}+\mathrm{H}]$ calcd for $\mathrm{C}_{16} \mathrm{H}_{16} \mathrm{BrN}_{4} \mathrm{O}_{4} 407.0355$, found: 407.0337; $[\mathrm{M}+\mathrm{H}]+2$ calcd for $\mathrm{C}_{16} \mathrm{H}_{16} \mathrm{BrN}_{4} \mathrm{O}_{4} 409.0334$, found: 409.0322 .

exo-5' - Thyminyl-2'-benzyl-spiro-[5-bromo-indoline-3, $3^{\prime}$ isoxazolidine]-2-one $7 \mathrm{~g}$. Yellow solid, $75 \%$ yield. ${ }^{1} \mathrm{H}$ NMR (500 MHz, DMSO-d $\left.{ }_{6}\right): \delta 1.82\left(\mathrm{~s}, 3 \mathrm{H}, \mathrm{CH}_{3}\right), 2.8-3,2\left(\mathrm{~m}, 2 \mathrm{H}, \mathrm{H}_{\mathrm{CH}_{2}}\right), 4.35$ $\left(\mathrm{s}, 2 \mathrm{H}, \mathrm{CH}_{2 \mathrm{Bn}}\right), 6.84(\mathrm{dd}, J=6.24 \mathrm{~Hz}, 8.85 \mathrm{~Hz}, 1 \mathrm{H}, \mathrm{CH}), 6.70-8.71$ (m, 8H, Ar), 8.98 (d, $\left.J=5.42 \mathrm{~Hz}, 1 \mathrm{H}, 6-\mathrm{CH}_{\text {Thy }}\right), 11.10\left(\mathrm{~s}_{\mathrm{b}}, 1 \mathrm{H}\right.$, $\mathrm{NH}), 11.36\left(\mathrm{~s}_{\mathrm{b}}, 1 \mathrm{H}, \mathrm{NH}_{\mathrm{Thy}}\right){ }^{13} \mathrm{C}$ NMR (125 MHz, DMSO-d $\left.\mathrm{d}_{6}\right)$ : $\delta$ 16.3, 33.3, 39.5, 67.0, 76.2, 113.6, 116.6, 117.7, 126.4, 132.1, 132.5 , 132.9, 133.5, 137.8, 142.5, 144.4, 146.6, 149.4, 155.6, 167.6. $\mathrm{ESI}(+)-\mathrm{MS}: m / z[\mathrm{M}+\mathrm{H}]$ calcd for $\mathrm{C}_{22} \mathrm{H}_{20} \mathrm{BrN}_{4} \mathrm{O}_{4} 483.0668$, found: 483.0666; $[\mathrm{M}+\mathrm{H}]+2$ calcd for $\mathrm{C}_{22} \mathrm{H}_{20} \mathrm{BrN}_{4} \mathrm{O}_{4} 485.0647$, found: 485.0637 .

exo-5'-Thyminyl-2'-benzyl-spiro-[5-nitro-indoline-3, $3^{\prime}$ isoxazolidine]-2-one $7 \mathbf{h}$. Orange solid, 74\% yield. ${ }^{1} \mathrm{H}$ NMR (300 MHz, DMSO-d ${ }_{6}$ ): $\delta 1.79\left(\mathrm{~s}, 3 \mathrm{H}, \mathrm{CH}_{3}\right), 3.54(\mathrm{dd}, J=7.03 \mathrm{~Hz}$, 14.22 Hz, $\left.1 \mathrm{H}, \mathrm{H}_{\mathrm{CH}_{2}}\right), 3.93-4.19\left(\mathrm{~m}, 3 \mathrm{H}, \mathrm{H}_{\mathrm{CH}_{2}}+\mathrm{CH}_{2 \mathrm{Bn}}\right), 5.48$ (dd, $J$ $=7.03 \mathrm{~Hz}, 9.72 \mathrm{~Hz}, 1 \mathrm{H}, \mathrm{CH}), 6.92(\mathrm{~d}, J=8.52 \mathrm{~Hz}, 1 \mathrm{H}, \mathrm{Ar}), 7.20-$ $7.78(\mathrm{~m}, 6 \mathrm{H}, \mathrm{Ar}), 8.15(\mathrm{dd} J=2.35 \mathrm{~Hz}, 8.70,1 \mathrm{H}, \mathrm{Ar}), 8.23$ (d, $J=$ $\left.2.19 \mathrm{~Hz}, 1 \mathrm{H}, 6-\mathrm{CH}_{\text {Thy }}\right), 11.03\left(\mathrm{~s}_{\mathrm{b}}, 1 \mathrm{H}, \mathrm{NH}\right), 11.12\left(\mathrm{~s}_{\mathrm{b}}, 1 \mathrm{H}, \mathrm{NH}_{\text {Thy }}\right)$ ${ }^{13} \mathrm{C}$ NMR (75 MHz, DMSO-d ${ }_{6}$ ): $\delta$ 12.6, 22.5, 29.4, 58.7, 71.2, $108.8,109.9,120.5,126.4,127.1,128.7,132.0,132.8,137.8$, 142.8, 145.0, 148.9, 151.5, 163.7, 180.3. $\operatorname{ESI}(+)-\mathrm{MS}: m / z[\mathrm{M}+\mathrm{H}]$ calcd for $\mathrm{C}_{22} \mathrm{H}_{20} \mathrm{~N}_{5} \mathrm{O}_{6} 450.1414$, found: 450.1403 .

exo-5' -Thyminyl-2' $^{\prime}$-methyl-spiro-[indane-3, $\mathbf{3}^{\prime}$-isoaxazolidine]

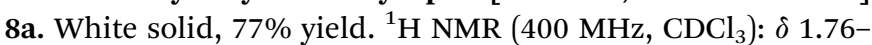
$1.90\left(\mathrm{~m}, 2 \mathrm{H}, \mathrm{CH}_{2}\right), 1.94\left(\mathrm{~d}, J=1.08 \mathrm{~Hz}, 1 \mathrm{H}, \mathrm{CH}_{3}\right), 2.38(\mathrm{~s}, 3 \mathrm{H}$, $\mathrm{CH}_{3}$ ), 2.51-2.67 (m, 2H, $\mathrm{CH}_{2}$ ), 2.79-3.05 (m, 2H, $\mathrm{CH}_{2}$ ), 6.20 (dd, $J$ $=5.68 \mathrm{~Hz}, 7.36 \mathrm{~Hz}, 1 \mathrm{H}, \mathrm{CH}), 7.12-7.35(\mathrm{~m}, 4 \mathrm{H}, \mathrm{Ar}), 7.79(\mathrm{~s}, 1 \mathrm{H}, 6-$ $\left.\mathrm{CH}_{\text {Thy }}\right), 9.39\left(\mathrm{~s}_{\mathrm{b}}, 1 \mathrm{H}, \mathrm{NH}_{\text {Thy }}\right) \cdot{ }^{13} \mathrm{C}$ NMR $\left(100 \mathrm{MHz}, \mathrm{CDCl}_{3}\right): \delta 12.8$, 29.2, 30.2, 36.1, 51.6, 77.9, 82.2, 111.1, 123.6, 125.2, 126.9, 129.0, 135.9, 139.8, 144.3, 150.7, 164.2. ESI(+)-MS: $m / z[\mathrm{M}+\mathrm{H}]$ calcd for $\mathrm{C}_{17} \mathrm{H}_{20} \mathrm{~N}_{3} \mathrm{O}_{3}$ 314.1505, found: 314.1497 .

exo-5'-Uracil-2' -methyl-spiro-[indane-3,3'-isoaxazolidine] 8 b. White solid, 76\% yield. ${ }^{1} \mathrm{H}$ NMR (400 $\mathrm{MHz}, \mathrm{CDCl}_{3}$ ): $\delta$ 1.78-1.95 (m, 2H, $\mathrm{CH}_{2}$ ), 2.39 (s, 3H, $\left.\mathrm{CH}_{3}\right), 2.52-2.72\left(\mathrm{~m}, 2 \mathrm{H}, \mathrm{CH}_{2}\right), 2.79-$ $3.10\left(\mathrm{~m}, 2 \mathrm{H}, \mathrm{CH}_{2}\right), 5.77\left(\mathrm{~d}, J=8.02 \mathrm{~Hz}, 1 \mathrm{H}, 5-\mathrm{CH}_{\mathrm{Ura}}\right), 6.19$ (dd, $=5.38 \mathrm{~Hz}, 7.24 \mathrm{~Hz}, 1 \mathrm{H}, \mathrm{CH}), 7.10-7.40(\mathrm{~m}, 4 \mathrm{H}, \mathrm{Ar}), 8.05(\mathrm{~d}, J=$ $\left.8.02 \mathrm{~Hz}, 1 \mathrm{H}, 6-\mathrm{CH}_{\mathrm{Ura}}\right), 9.53\left(\mathrm{~s}_{\mathrm{b}}, 1 \mathrm{H}, \mathrm{NH}_{\mathrm{Ura}}\right) \cdot{ }^{13} \mathrm{C} \mathrm{NMR}(100 \mathrm{MHz}$, $\left.\mathrm{CDCl}_{3}\right): \delta 29.4,30.1,35.9,78.0,82.6,102.6,123.6,125.1,127.0$, 129.1, 139.5, 140.3, 144.3, 150.6, 163.7. ESI(+)-MS: $m / z[\mathrm{M}+\mathrm{H}]$ calcd for $\mathrm{C}_{16} \mathrm{H}_{18} \mathrm{~N}_{3} \mathrm{O}_{3} 300.1348$, found: 300.1337 .

\section{Conclusions}

In summary, we have initially developed an environmentally benign and fast method by microwave irradiation and solventfree conditions for the synthesis of significant number of substituted isatinyl and indanyl nitrones as important precursors of spiro-isoxazolidines. Then, we applied a MW-assisted 1,3-dipolar cycloaddition to some previously synthesized ketonitrones as dipole and vinylthymine or vinyluracil as dipolarophile, obtaining nucleobase-containing spiro-isoxazolidines with indoline or indane ring in good yields, excellent regioisomery and high diastereoisomery. The importance of this application is surely the direct insertion of a nucleobase on spiroisoxazolidines with indoline or indane scaffold that in our opinion represents a great chemical novelty. Finally, we have also enriched this work, studying by theoretical calculations the effect of various substituents about the reactivity of the carbonyl groups with different hydroxylamines in synthesis of nitrones.

\section{Conflicts of interest}

There are no conflicts to declare.

\section{Acknowledgements}

We thank the Italian Ministry of University and Scientific Research (MIUR) for a doctoral grant and the University of Calabria for financial support. Thanks to the Ministerio de Ciencia e Innovación (MICINN) and FEDER Program (Madrid, Spain, project CTQ2016-76155-R) and the Gobierno de Aragón (Zaragoza, Spain. Bioorganic Chemistry Group. E-10). We acknowledge the Institute of Biocomputation and Physics of Complex Systems (BIFI) at the University of Zaragoza (Spain) for computer time at clusters.

\section{Notes and references}

1 C. V. Galliford and K. A. Scheidt, Angew. Chem., Int. Ed., 2007, 46, 8748.

2 D. Cheng, Y. Ishihara, C. F. Barbas III and B. Tan, ACS Catal., 2014, 4, 743.

3 B. Tan, X. Zeng, W. W. Y. Leong, Z. Shi, C. F. Barbas III and G. Zhong, Chem.- Eur. J., 2012, 18, 63.

4 M. C. Pirrung, S. V. Pansare, K. D. Sarma, K. A. Keith and E. R. Kern, J. Med. Chem., 2005, 48, 3045.

5 D. J. Bauer and P. W. Sadler, Nature, 1961, 190, 1167.

6 J. M. Z. Gladich, J. H. Hunt, D. Jack, R. F. Haff, J. J. Boyle, R. C. Stewart and R. J. Ferlauto, Nature, 1969, 221, 286.

7 D. Sriram, T. R. Bal and P. Yogeeswari, J. Pharm. Pharm. Sci., 2005, 8, 565.

8 K. Ding, Y. Lu, Z. Nikolovska-Coleska, G. Wang, S. Qiu, S. Shangary, W. Gao, D. Qin, J. Stuckey, K. Krajewski, P. P. Roller and S. Wang, J. Med. Chem., 2006, 49, 3432.

9 S. Wang, Y. Zhao, D. Bernard, A. Aguilar and S. Kumar, Top. Med. Chem., 2012, 8, 57.

10 F. Shi, Z.-L. Tao, S.-W. Luo, S.-J. Tu and L.-Z. Gong, Chem.Eur J., 2012, 18, 6885. 
11 C.-S. Wang, R.-Y. Zhu, J. Zheng, F. Shi and S.-J. Tu, J. Org. Chem., 2015, 80, 512.

12 W. Dai, X.-L. Jiang, Q. Wu, F. Shi and S.-J. Tu, J. Org. Chem., 2015, 80, 5737.

13 C. Chavarría, D. I. Pérez, C. Pérez, J. Morales-García, S. Alonso-Gil, A. Pérez Castillo, C. Gil, J. Souza and W. Porcal, Eur. J. Med. Chem., 2012, 58, 44.

14 V. Gautheron-Chapoulaud, S. U. Pandya, P. Cividino, G. Masson, S. Py and Y. Vallée, Synlett, 2001, 8, 1281.

15 G. Masson, S. Py and Y. Valleé, Angew. Chem., Int. Ed., 2002, 41, 1772.

16 H. I. Petkes, E. Gal, L. Gaina, M. Sabou, C. Majdik and L. Silaghi-Dumitrescu, C. R. Chim., 2014, 17, 1050.

17 G. Soldaini, F. Cardona and A. Goti, Org. Lett., 2007, 9, 473. 18 S. Franco, F. L. Merchant, P. Merino and T. Tejero, Synth. Commun., 1995, 25, 2275.

19 Y. Tomioka, C. Nagahiro, Y. Nomura and H. Maruoka, J. Heterocycl. Chem., 2003, 40, 121.

20 R. Y. Suman, P. Kadigachalam, V. R. Doddi and Y. D. Vankar, Tetrahedron Lett., 2009, 50, 5827.

21 H. G. Aurich and W. Weiss, Tetrahedron, 1976, 32, 159.

22 K. Torssell and O. Zeuthen, Acta Chem. Scand., Ser. A, 1978, 32, 118.

23 H. Valizadeh, Heteroat. Chem., 2010, 21, 78.

24 H.-B. Yang and S. Min, Org. Biomol. Chem., 2012, 10, 8236.

25 Y.-H. Zhang, M.-Y. Wu and W.-C. Huang, RSC Adv., 2015, 5, 105825.

26 I. S. Young and M. A. Kerr, Angew. Chem., Int. Ed., 2003, 26, 3023.

27 S.-Y. Wu, X.-P. Ma, C. Liang and D.-L. Mo, J. Org. Chem., 2017, 3232.
28 A. Loupy, in Microwave in Organic Synthesis, Wiley-VCH, Weinheim, 2002.

29 J. P. Tieney and P. Lidstrom, in Microwave Assisted Organic Chemistry, Blackwell Publishing, Oxford, 2005.

30 L. Maiuolo, A. De Nino, P. Merino, B. Russo, G. Stabile, M. Nardi, N. D'Agostino and T. Bernardi, Arabian J. Chem., 2016, 9, 25.

31 F. M. Murphy and M. J. Meegan, J. Chem. Res., Miniprint, 1996, 301.

32 T. B. Nguyen, A. Martel, R. Dhal and G. Dujardin, Synthesis, 2009, 18, 3174.

33 B. S. Furniss; A. J. Hannaford; P. W. G. Smith and A. R. Tatchell, in Vogel's, Textbook of Practical Organic Chemistry, Pearson Education Limited, 1989.

34 C. S. Marvel and O. Kamm, J. Am. Chem. Soc., 1919, 41, 276. 35 J. Khazir, P. P. Singh, D. M. Reddy, I. Hyder, S. Shafi, S. D. Sawant, G. Chashoo, A. Mahajan, M. S. Alam, A. K. Saxena, S. Arvinda, B. D. Gupta and H. M. S. Kumar, Eur. J. Med. Chem., 2013, 63, 279.

36 Raunak, V. Kumar, S. Mukherjee, Poonam, A. K. Prasad, C. E. Olsen, S. J. C. Schäffer, S. K. Sharma, A. C. Watterson, W. Errington and V. S. Parmar, Tetrahedron, 2005, 61, 5687.

37 S. Malhotra, S. Balwani, A. Dhawan, B. K. Singh, S. Kumar, R. Thimmulappa, S. Biswal, C. E. Olsen, E. Van der Eycken, A. K. Prasad, B. Ghosh and V. S. Parmar, Med. Chem. Commun., 2011, 2, 743.

38 J. M. Vorbrüggen, K. Kvolikiewicz and B. Bennua, Chem. Ber., 1981, 114, 1234-1255.

39 R. Dalpozzo, A. De Nino, L. Maiuolo, A. Procopio, R. Romeo and G. Sindona, Synthesis, 2002, 2, 172-174.

40 O. Bortolini, A. De Nino, T. Eliseo, R. Gavioli, L. Maiuolo, B. Russo and F. Sforza, Bioorg. Med. Chem., 2010, 18, 6970. 